\title{
The current state of research on energy communities
}

\author{
L. Gruber(D, U. Bachhiesl, S. Wogrin
}

\begin{abstract}
The introduction of the Clean energy for all Europeans package by the European Union (EU) led to a significant boost of public and research interest in energy communities. However, since neither their definition nor their goals are clearly defined, there is a very broad field of research on this topic. This paper aims to classify existing research on energy communities and to analyze what this umbrella term looks like in the literature. First, a literature review is conducted with regard to energy communities that have a local scope and are community-owned. The analysis of the results leads to the determination of the following categories for the existing literature on energy communities: the terminology used to refer to energy communities, components of energy communities, and their characteristics and structure. The review affirms that space-saving and easily constructible components are used the most, with photovoltaics (PV) and storage at the forefront. Our results also show that a third-party aggregator can be a vital part of an energy community with various functions, from managing the community's energy flow and local market to trading energy with the grid. Taking this into consideration, we conclude that the use of aggregators is a good way to make the formation of energy communities easier, especially for people without an engineering background.
\end{abstract}

Keywords: energy communities; community energy; renewable energy; distributed generation

\section{Der aktuelle Stand der Forschung zu Energiegemeinschaften.}

Die Einführung des Pakets "Saubere Energie für alle Europäer" von der Europäischen Union (EU) führte zu einem deutlichen Anstieg des öffentlichen und wissenschaftlichen Interesses an Energiegemeinschaften. In diesem Beitrag wird die Forschung dazu analysiert, um herauszufinden, wie dieser Sammelbegriff in der Literatur aussieht. Um diese Frage zu beantworten, definieren wir zunächst Eckpunkte einer Energiegemeinschaft und führen anschließend zwei Literaturrecherchen durch. Die Ergebnisse werden analysiert, was zur Ermittlung von relevanten Kategorien führt. Diese bestehen aus den Begriffen für Energiegemeinschaften, deren Komponenten sowie deren Eigenschaften und Struktur. Die Analyse zeigt, dass platzsparende und einfach zu installierende Komponenten am häufigsten verwendet werden, wobei PV-Anlagen und Speicher an erster Stelle stehen. Unsere Ergebnisse zeigen auch, dass ein externer Aggregator ein wichtiger Teil einer Energiegemeinschaft mit verschiedenen Funktionen sein kann, von der Verwaltung des Energieflusses und des lokalen Marktes der Gemeinschaft bis hin zum Energiehandel mit dem Netz. In Anbetracht dessen kommen wir zu dem Schluss, dass der Einsatz von Aggregatoren ein guter Weg ist, um die Bildung von Energiegemeinschaften zu erleichtern, insbesondere für Personen ohne technischen Hintergrund.

Schlüsselwörter: Energiegemeinschaften; Bürgerenergie; erneuerbare Energien; dezentrale Energieversorgung

Received July 12, 2021, accepted September 17, 2021, published online October 4, 2021

(C) The Author(s) 2021

\section{Introduction}

The rapid expansion of renewable energy generation demands altering our energy system from a purely centralized top-down to a more distributed bottom-up structure. One part of this process will be the formation and integration of energy communities (ECs). They emphasize consumption of renewable energy where it is produced and therefore decrease the need for very expensive grid expansion measures, as well as combating communal opposition towards renewables by directly involving consumers. This gives citizens the opportunity to be informed about and benefit from renewables. ECs are not a completely new concept, e.g. Ecopower in Belgium which was founded in 1991 out of a co-housing project with a community watermill [1]. The Clean Energy for all Europeans Package [2] by the EU gave researchers a new motivation to work on the topic. It also pushes European countries to introduce legislation that makes it possible to implement ECs more widespread.

The literature reviews discovered during our search were primarily concerned with the benefits and drawbacks of ECS in specific countries [3-5]. Vernay and Sebi in [3] investigate the characteristics that ecosystems surrounding ECs require in order to form, develop, and mature. Their paper's geographical focus is on France and the Netherlands. The literature review [4] from Meister et al. focuses on energy cooperatives in Germany and Switzerland. The authors examine national frameworks and support schemes, as well as municipal assistance. In [5] Brummer discusses the advantages of community energy to society but also the challenges that can be encountered in the United States, Germany, and the United Kingdom. The most comprehensive of the encountered literature reviews is Koirala et al. [6]. They used a keyword ranking and clustering system to determine research trends in local energy systems, followed by a discussion of various integration options for integrated commu-

Gruber, Lia, Institute of Electricity Economics and Energy Innovation, Graz University of Technology, Inffeldgasse 18, 8010 Graz, Austria (E-mail: lia.gruber@tugraz.at); Bachhiesl, Udo, Institute of Electricity Economics and Energy Innovation, Graz University of Technology, Graz, Austria; Wogrin, Sonja, Institute for Research in Technology, School of Engineering, Comillas Pontifical University, Madrid, Spain 
nity energy systems (ICES). In addition, the authors examined technological, socioeconomic, environmental, and institutional barriers. Our literature review goes into another direction by focusing on the topology of the EC landscape. While Koirala et al. [6] determines and describes the technological options for EC integration, our goal is to analyze how their implementation can differ in the literature and what the most common EC configurations are.

This paper is organized as follows: Sect. 2 describes the applied search and classification methodology. In Sect. 3 the results are presented. Section 3.1 discusses the terms used and their definitions Section 3.2 looks at the components of the EC and Sect. 3.3 analyzed their characteristics and structure. Finally, Sect. 4 concludes this work.

\section{Methodology}

First, let us define the term energy community in the context of this paper. The geographic scope of the ECs chosen for this literature review was local, such as a neighborhood or a microgrid. This decision was made because it is more interesting from a technological standpoint in our opinion. In particular, the fact that the energy production is geographically close to the production aids in mitigating the strain that major installation of renewable energy can have on the grid structure. It also enables the sharing of energy and storage not only on paper but also physically. An energy community with members from all over the country, for example, owning and operating a wind power plant together, may be more economically appealing, but this is not the purpose of this paper. A similar differentiation was made by the European Union in its Clean Energy for all Europeans Package [2] by defining two types of ECs: the citizen energy community (CEC) and the renewable energy community (REC). The main differences between the two are that members of the REC need to be geographically close to their assets and CECs are also permitted to generate energy that is fossil fuel based as well as renewable $[7,8]$.

RECs are defined in Article 2 of the Renewable Energy Directive [7] as follows: "'renewable energy community' means a legal entity: (a) which, in accordance with the applicable national law, is based on open and voluntary participation, is autonomous, and is effectively controlled by shareholders or members that are located in the proximity of the renewable energy projects that are owned and developed by that legal entity; (b) the shareholders or members of which are natural persons, SMEs or local authorities, including municipalities; (c) the primary purpose of which is to provide environmental, economic or social community benefits for its shareholders or members or for the local areas where it operates, rather than financial profits;"

Later in Article 22 their services are described: "Member States shall ensure that renewable energy communities are entitled to: (a) produce, consume, store and sell renewable energy, including through renewables power purchase agreements; (b) share, within the renewable energy community, renewable energy that is produced by the production units owned by that renewable energy community, subject to the other requirements laid down in this Article and to maintaining the rights and obligations of the renewable energy community members as customers; (c) access all suitable energy markets both directly or through aggregation in a nondiscriminatory manner."

The search term "Renewable Energy Community" (REC) is used to include the local scope. Only peer-reviewed journal or conference papers and literature from the years 2000 to 2021 are considered. First, a more general literature search was conducted using Google Scholar and Science Direct. The second search in Semantic Scholar

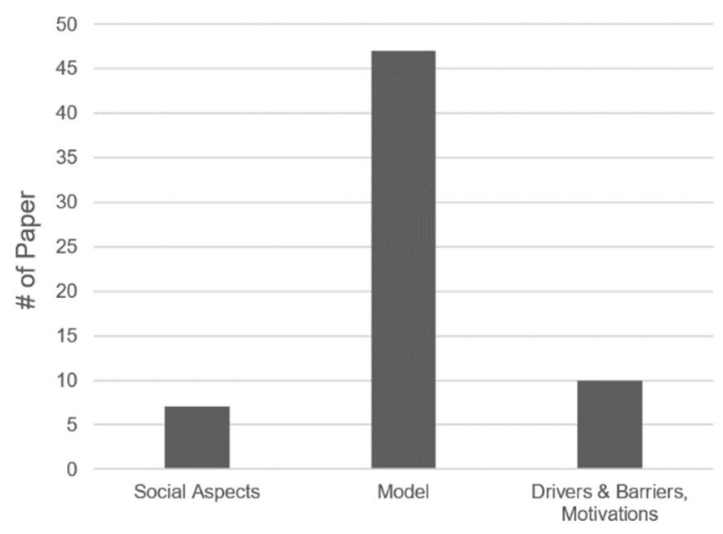

Fig. 1. Classification of papers by general topic

was more systematic. Semantic Scholar found 32,200 papers with the mentioned term in the following fields of study: Business, Computer Science, Economics, Engineering, and Mathematics. The 100 most relevant papers in each study field as determined by the algorithm were examined more closely to see if they met the set definition.

During the paper analysis three general paper topics became apparent. First papers on social aspects of ECs e.g. in [9] McCabe et al. propose combining community energy with social housing as a means of combating energy poverty. The second topic is models that depict an EC while optimizing a set variable, such as energy cost or consumption. Lastly, papers determining the drivers and barriers of ECs, such as the above mentioned literature reviews [3-5]. Another good example is [10], in which Soeiro and Dias investigate the motivations for joining an EC. As illustrated in Fig. 1, 10\% of the analyzed papers look into social aspects of ECs. About 15\% evaluate drivers and barriers of an EC. Out of the 67 assessed papers the vast majority includes a model of an EC. As a result, this article focuses on this paper topic and because the other two don't fall into the chosen technological focus.

The resulting papers were first sorted by Keywords and then clustered. Unfortunately, those Keyword clusters alone were not informative enough to serve as well describing categories. Furthermore, they showed how widespread the structure and characteristics of energy communities are in literature. Therefore, the next step was to look deeper in order to find suited categories to organize the findings. The first aspect that stood out was that the "terminology" used for ECs was not at all uniform. This raised the question of whether the various terms described the same thing or not. Therefore, this was chosen as the first category to create an overview of the many terms in literature and their definitions. With an often missing unique and descriptive terminology, the EC's components and characteristics proved to be more distinguishing features. The second category "components" is made up of power generation types, storage devices and heating/cooling methods (e.g. PV or heat pumps (HP)). It provides an answer to the question, "What is used to supply the EC with the energy it requires?". The last category is "characteristics and structure". The goal here was to learn how the EC manages its energy production and demand (e.g. aggregator or demand side management), as well as how its members interact with one another and the grid/market outside the EC (e.g. peer to peer trading). 


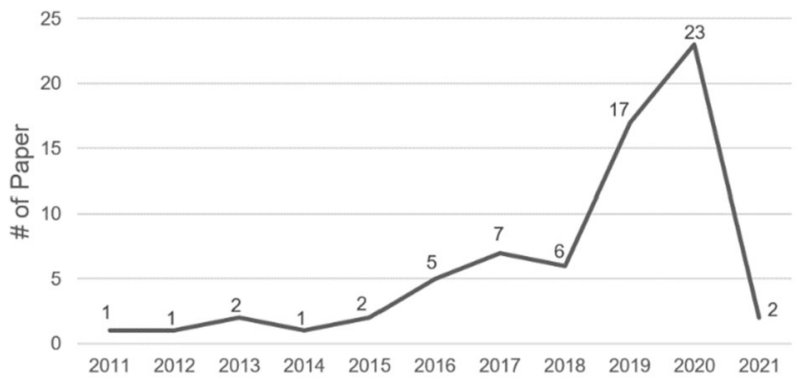

Fig. 2. Literature output sorted per year

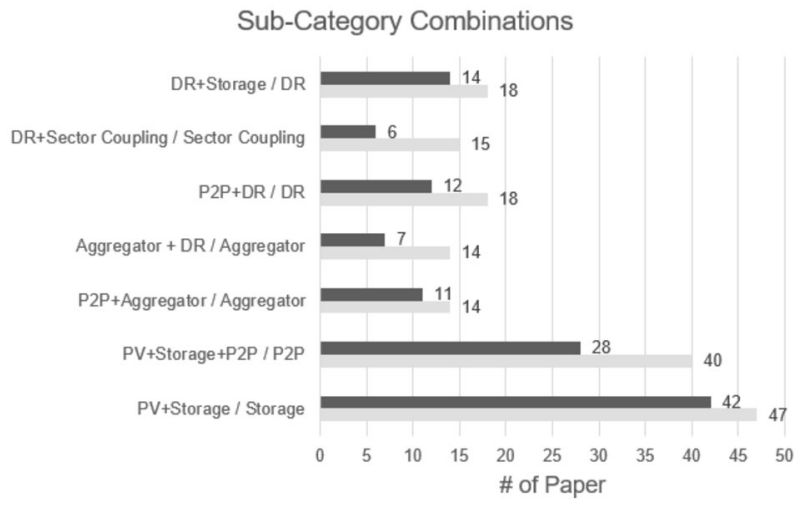

Fig. 3. Sub-Category Combinations

Therefore, the papers were further analyzed and labeled with tags from three categories:

- Terminology used to refer to an energy community

- Components of an energy community

- Characteristics and structure of an energy community

\section{Results}

This chapter presents the results of the review. The literature search resulted in a total of 67 papers. Figure 2 depicts the number of discovered papers published each year. The plot clearly shows that research interest increased significantly after the European Union passed REDII [7] in 2018. Table 1 was created to help visualize the results. It indicates which analyzed papers contain which subcategories of Sects. 3.2 and 3.3. To better illustrate some interesting combinations of the sub-categories, that also can be seen in Table 1 Fig. 3 was created. PV with storage is the most common combination ( $90 \%$ of the paper involving storage). PV and storage were described as components in $70 \%$ of the peer-to-peer trading (P2P) papers. This is consistent with the fact that those two components are the most widely used. It is not surprising that nearly $80 \%$ of the aggregator papers had a P2P system in place, as one of the major roles of an aggregator is to manage the EC's internal market. Another function of an aggregator is to manage DR in the community, as exampled by half of the aggregator papers. Another interesting combination is P2P and DR, since DR can be used to get more out of P2P. Storage is an important aspect of disaster recovery, as shown in Fig. 3. The combination of DR and sector coupling is less common, appearing in only about half of the sector coupling papers.

\subsection{Terminology used to refer to an energy community} In this section, the various terminology used to name the ECs is compared. Because energy communities are such a novel topic, many

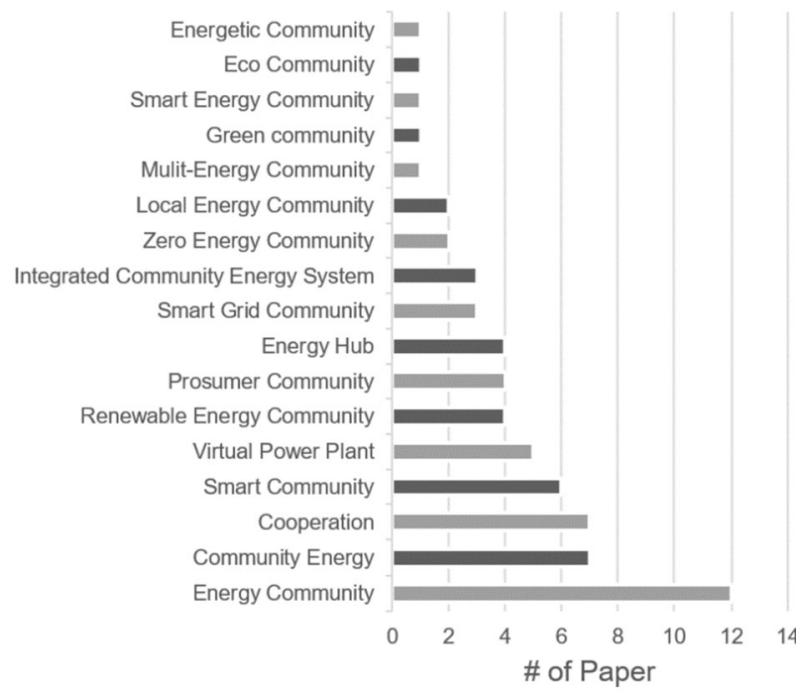

Fig. 4. Classification of papers by terminology used to refer to an energy community

researchers developed their own terminology to describe ECs. This creates uncertainty as to whether they are writing about something similar or the same. As a result, we felt it was necessary to organize and describe those numerous definitions. Figure 4 depicts the 17 terms found in the literature, sorted by occurrences. The two most often used are community energy (CE) and energy community which can be understood as umbrella terms meaning many different structures and services can be involved in them. In [5] Brummer, in order to describe $C E$, the author tried to define the word community first. To then just include the energy component by adding heat and/or electricity generation and/or distribution as its activity. They also concluded that community (energy) is an umbrella term that needs to be contextualized since it can have a social and a geographical scope.

This definition is not only adopted and/or referenced by all papers using the term REC $[10,11,22,30,44,72]$ but the phrase that ECs can "produce, consume, store and sell renewable energy" summarizes all the definitions found in literature. Another term often used in the context of ECs is the concept of a cooperation where people (members) run and own operating equipment as a collective. This business model has a long history in many countries and has been applied in different sectors e.g. for agricultural machinery [73]. The European countries were energy cooperatives are most common are Germany, Denmark, Austria, Great Britain, and Switzerland in that order. In some countries the term is a separate legal form (e.g. Genossenschaft in DE and AT) in others just the concept of cooperations is used [4]. In [20] Capaccioli et al. design two cooperations in Italy and conclude that the cooperation values that come with this concept are a big part why people participate. Their results also show that cooperations lead to better relationships between actors involved in their energy system. In the analyzed literature the term smart community is only defined in two papers. First in [63] Wang et al. use the very general "produce, consume, store and sell renewable energy" definition mentioned above. Yahaya et al. in [65] on the other hand focuses on the word "smart" meaning appliances and infrastructure equipped with information and communication technology for easier energy management. In general, it can be said that the practice of using but not defining a term has been very common in the analyzed literature. This led to smart grid community, green community and energetic community falling under 
Table 1. Research sub-categories and references

\begin{tabular}{|c|c|c|c|c|c|c|c|c|c|c|c|c|c|c|c|}
\hline & DG & PV & Wind & Hydro & $\begin{array}{l}\text { Bio } \\
\text { mass }\end{array}$ & $\begin{array}{l}\text { Energy } \\
\text { storage }\end{array}$ & EV & $\mathrm{CHP}$ & $\mathrm{HP}$ & $\begin{array}{l}\text { Sector } \\
\text { coupling }\end{array}$ & $\begin{array}{l}\text { Aggre- } \\
\text { gator }\end{array}$ & $\mathrm{DR}$ & $\begin{array}{l}\mathrm{P} 2 \mathrm{P} \\
\text { trading }\end{array}$ & $\begin{array}{l}\text { Block- } \\
\text { chain }\end{array}$ & $\begin{array}{l}\text { Micro } \\
\text { - grid }\end{array}$ \\
\hline $\begin{array}{l}\text { Abada, } 2020 \\
\text { [11] }\end{array}$ & & $x$ & & & & $x$ & & & & & & & $x$ & & $x$ \\
\hline $\begin{array}{l}\text { Adu-Kankam, } \\
2019 \text { [12] }\end{array}$ & & $x$ & $x$ & & $x$ & $x$ & $x$ & $x$ & & $x$ & & & $x$ & $\mathrm{x}$ & $x$ \\
\hline $\begin{array}{l}\text { Al Skaif, } 2017 \\
\text { [13] }\end{array}$ & & $x$ & & & & $x$ & & & & & & & & & $x$ \\
\hline Alam, 2013 [14] & & $x$ & $x$ & & & $x$ & & & & & & & $x$ & & \\
\hline $\begin{array}{l}\text { Albachrony, } \\
2019 \text { [15] }\end{array}$ & & $x$ & & & & $x$ & & & & & & $x$ & $x$ & & \\
\hline Belli, 2017 [16] & & $x$ & $\mathrm{x}$ & & & $x$ & & $x$ & & & $x$ & $x$ & $x$ & & \\
\hline Bere, 2017 [17] & & & & $\mathrm{x}$ & & & & & & & & & & & \\
\hline $\begin{array}{l}\text { Bottaccioli, } \\
2015 \text { [18] }\end{array}$ & & $\mathrm{x}$ & & & & & & & & & $\mathrm{x}$ & & & & \\
\hline $\begin{array}{l}\text { Brummer, } 2018 \\
\text { [5] }\end{array}$ & & $x$ & $x$ & & & $x$ & & $x$ & & $x$ & & & & & \\
\hline $\begin{array}{l}\text { Cabrera, } 2016 \\
\text { [19] }\end{array}$ & & $x$ & & & & & & & & & & & & & $x$ \\
\hline $\begin{array}{l}\text { Capaccioli, } 2016 \\
\text { [20] }\end{array}$ & $x$ & & & & & & & & & & & & & & \\
\hline $\begin{array}{l}\text { Cardoso, } 2019 \\
{[21]}\end{array}$ & & $x$ & $x$ & $\mathrm{x}$ & & $x$ & & & & & & & $x$ & & \\
\hline Cejka, 2020 [22] & & $x$ & & & & $x$ & & & & & & & $x$ & $x$ & \\
\hline Chen, 2015 [23] & & $x$ & $x$ & & & $x$ & & & & & & & $x$ & & \\
\hline $\begin{array}{l}\text { Cheng, } 2020 \\
{[24]}\end{array}$ & & $x$ & & & & $x$ & $x$ & & & & $x$ & $x$ & $x$ & & \\
\hline Chis, 2019 [25] & & & $x$ & & & $x$ & & & & & & $x$ & $x$ & & \\
\hline Chis, 2016 [26] & & $x$ & $x$ & & & $x$ & & & & & $x$ & $x$ & $x$ & & \\
\hline $\begin{array}{l}\text { Crespo- } \\
\text { Vazquez, } 2021 \\
{[27]}\end{array}$ & & $x$ & & & & $x$ & & & & & & & $x$ & & \\
\hline Cruz, 2019 [28] & $x$ & & & & & & & & & & $x$ & $x$ & & & \\
\hline Cui, 2020 [29] & & $x$ & & & & $x$ & & & & & $x$ & & $\mathrm{x}$ & & \\
\hline $\begin{array}{l}\text { De Villena, } 2020 \\
\text { [30] }\end{array}$ & & $x$ & & & & & & & & & & $x$ & $\mathrm{x}$ & & \\
\hline Faia, 2021 [31] & & $x$ & & & & $x$ & & & & & & & $x$ & & \\
\hline Fazeli, 2011 [32] & & $x$ & & & & $x$ & & $x$ & & $x$ & & $x$ & & & \\
\hline $\begin{array}{l}\text { Fouad, } 2020 \\
\text { [33] }\end{array}$ & & $x$ & $x$ & & & & & & & $x$ & & & & & \\
\hline $\begin{array}{l}\text { Giordano, } 2020 \\
\text { [34] }\end{array}$ & & $x$ & & & & $x$ & & & & & & & $x$ & & \\
\hline Good, 2019 [35] & & $x$ & $x$ & & & $x$ & & $x$ & $x$ & $x$ & & $x$ & & & \\
\hline $\begin{array}{l}\text { Grosspietsch, } \\
2018 \text { [36] }\end{array}$ & & $x$ & & & & $x$ & & $x$ & $x$ & $x$ & & & & & \\
\hline Guo, 2019 [37] & & $x$ & & & & $x$ & $x$ & $x$ & $x$ & $x$ & & $x$ & & & \\
\hline $\begin{array}{l}\text { Jenkins, } 2020 \\
\text { [38] }\end{array}$ & $x$ & & & & & & & & & & $x$ & & $x$ & & \\
\hline Koirala, 2016 [6] & & $x$ & $x$ & & $x$ & $x$ & $x$ & $x$ & $x$ & $x$ & $x$ & $x$ & $x$ & & $x$ \\
\hline Kong, 2020 [39] & $x$ & & & & & $x$ & & & & & & & $x$ & & \\
\hline $\begin{array}{l}\text { Leithon, } 2019 \\
\text { [40] }\end{array}$ & & $x$ & & & & $x$ & & & & & & & $x$ & & \\
\hline $\begin{array}{l}\text { McCabe, } 2018 \\
\text { [9] }\end{array}$ & & $x$ & & & & & & $x$ & & & & & & & \\
\hline $\begin{array}{l}\text { Mediwaththe, } \\
2020 \text { [41] }\end{array}$ & & $x$ & & & & $x$ & & & & & $x$ & & $x$ & & \\
\hline $\begin{array}{l}\text { Mehinovic, } \\
2020[42]\end{array}$ & & $x$ & & & & & & & & & & $x$ & $x$ & & \\
\hline
\end{tabular}


Table 1. (Continued)

\begin{tabular}{|c|c|c|c|c|c|c|c|c|c|c|c|c|c|c|c|}
\hline & DG & PV & Wind & Hydro & $\begin{array}{l}\text { Bio } \\
\text { mass }\end{array}$ & $\begin{array}{l}\text { Energy } \\
\text { storage }\end{array}$ & EV & $\mathrm{CHP}$ & $\mathrm{HP}$ & $\begin{array}{l}\text { Sector } \\
\text { coupling }\end{array}$ & $\begin{array}{l}\text { Aggre- } \\
\text { gator }\end{array}$ & $\mathrm{DR}$ & $\begin{array}{l}\mathrm{P} 2 \mathrm{P} \\
\text { trading }\end{array}$ & $\begin{array}{l}\text { Block- } \\
\text { chain }\end{array}$ & $\begin{array}{l}\text { Micro } \\
\text { - grid }\end{array}$ \\
\hline $\begin{array}{l}\text { Meinke, } 2020 \\
\text { [43] }\end{array}$ & & $x$ & & & & & & $x$ & & $x$ & & & & & \\
\hline $\begin{array}{l}\text { Meister, } 2020 \\
\text { [4] }\end{array}$ & & $x$ & $x$ & & & & & & & $x$ & & & & & \\
\hline $\begin{array}{l}\text { Moura, } 2020 \\
{[44]}\end{array}$ & & $x$ & & & & $x$ & $x$ & & & & $x$ & & $x$ & & \\
\hline $\begin{array}{l}\text { Negeri, } 2012 \\
{[45]}\end{array}$ & & $x$ & & & & $x$ & $x$ & $x$ & & & & & $x$ & & \\
\hline $\begin{array}{l}\text { Nidhin, } 2019 \\
\text { [46] }\end{array}$ & & $x$ & $x$ & & & & & & & & & & $x$ & $x$ & \\
\hline $\begin{array}{l}\text { Okpako, } 2017 \\
{[47]}\end{array}$ & & $x$ & & & & $x$ & & & & & & & & & \\
\hline $\begin{array}{l}\text { Okpako, } 2018 \\
\text { [48] }\end{array}$ & & & & & & $x$ & $x$ & & & & $x$ & & & & \\
\hline $\begin{array}{l}\text { Olivella-Rosell, } \\
2018 \text { [49] }\end{array}$ & & $x$ & & & & $x$ & $x$ & & & & $x$ & $x$ & $x$ & & \\
\hline $\begin{array}{l}\text { Oprea, } 2020 \\
{[50]}\end{array}$ & $x$ & & & & & & & & & & & & $x$ & $x$ & \\
\hline Petri, 2020 [51] & & $x$ & $x$ & $x$ & & & & & & & & & $x$ & $x$ & \\
\hline $\begin{array}{l}\text { Pholboon, } 2016 \\
\text { [52] }\end{array}$ & & $x$ & & & & $x$ & & & & & & $x$ & & & \\
\hline $\begin{array}{l}\text { Prasad, } 2019 \\
\text { [53] }\end{array}$ & & $x$ & & & & $x$ & & & & & & & $x$ & & $x$ \\
\hline $\begin{array}{l}\text { Rastegar, } 2017 \\
{[54]}\end{array}$ & & $x$ & & & & $x$ & $x$ & $x$ & & $x$ & & & & & \\
\hline $\begin{array}{l}\text { Rathnayaka, } \\
2014 \text { [55] }\end{array}$ & & $x$ & $x$ & & & $x$ & & & & & & & $x$ & & \\
\hline Reis, 2019 [56] & & $x$ & & & & $x$ & $x$ & & & $x$ & & $x$ & $x$ & & \\
\hline Sato, 2020 [57] & & $x$ & & & & $x$ & & & & & & & & & \\
\hline $\begin{array}{l}\text { Savelli, } 2019 \\
\text { [58] }\end{array}$ & $x$ & & & & & $x$ & & & & & & & $x$ & & $x$ \\
\hline $\begin{array}{l}\text { Saxena, } 2019 \\
\text { [59] }\end{array}$ & & $x$ & & & & $x$ & $x$ & & & & & & $x$ & $x$ & $x$ \\
\hline $\begin{array}{l}\text { Scheller, } 2018 \\
{[60]}\end{array}$ & & $x$ & & & & $x$ & & $x$ & $x$ & $x$ & & $x$ & & & \\
\hline $\begin{array}{l}\text { Schiera, } 2019 \\
{[61]}\end{array}$ & & $x$ & & & & & & & & & & & $x$ & & \\
\hline $\begin{array}{l}\text { Seven, } 2020 \\
{[62]}\end{array}$ & & $x$ & $x$ & & & $x$ & $x$ & & & & & & $x$ & $x$ & \\
\hline $\begin{array}{l}\text { Soeiro, } 2020 \\
{[10]}\end{array}$ & $x$ & & & & & & & & & & & & & & \\
\hline Vernay, 2020 [3] & & $x$ & $x$ & & & & & & & & & & & & \\
\hline $\begin{array}{l}\text { Wang, } 2019 \\
\text { [63] }\end{array}$ & & $x$ & & & & $x$ & $x$ & & & & $x$ & & $x$ & & $x$ \\
\hline $\begin{array}{l}\text { Wijethunge, } \\
2019 \text { [64] }\end{array}$ & & & $x$ & & & & & & & & & & & & \\
\hline $\begin{array}{l}\text { Yahaya, } 2020 \\
\text { [65] }\end{array}$ & $x$ & & & & & $x$ & $x$ & & & & $x$ & $x$ & $x$ & $x$ & \\
\hline Yan, 2013 [66] & & $x$ & & & & $x$ & & $x$ & & $x$ & & & & & \\
\hline Ye, 2017 [67] & & $x$ & $x$ & & & $x$ & & & & & & & $x$ & & \\
\hline $\begin{array}{l}\text { Young, } 2017 \\
{[68]}\end{array}$ & & $x$ & $x$ & & $x$ & $x$ & & $x$ & & $x$ & & & & & $x$ \\
\hline $\begin{array}{l}\text { Zhang, } 2019 \\
\text { [69] }\end{array}$ & & $x$ & & & & & & & & & & $x$ & $x$ & & $x$ \\
\hline $\begin{array}{l}\text { Zhong, } 2020 \\
{[70]}\end{array}$ & & $x$ & & & & $x$ & & & & & & & & & \\
\hline Zou, 2020 [71] & & $x$ & & & & $x$ & & & & & & & $x$ & & \\
\hline
\end{tabular}


the EC umbrella but not being defined by any of the papers using them. On the other hand, there are a few well-defined terms with a more clear-cut description of structure and activities: virtual power plant, energy hub and integrated community energy system. A virtual power plant is a cluster of small load/generation entities that is aggregated as one market participant in order to provide flexibility to the system [47]. Such entities include pro- and consumers as well as small power plants (e.g. wind or solar) and storage systems [62]. An energy hub is characterized by going beyond electricity through utilizing an energy management system to maintain all energy needs of its members as efficient as possible [12, 37]. An integrated community energy system (ICES) is an integrated approach that can be seen as a micro-grid, also including other energy carriers than electricity, which is organized by its community [16]. A more detailed comparison of the three can be found in [6] by Koirala et al. A prosumer community is a group of prosumers that trade energy not only with the grid but also with each other to increase the level of efficiency within the community [71]. A zero-energy community is made up of zero energy buildings that have a net zero energy consumption over the course of a year [53]. The definition used for local energy community in [31] by Faia et al. and [49] by Olivella-Rosell et al. is equal to the general REC definition by the EU. The eco community described by Yan et al. in [66] is also very similar with the explicit goal to be as self-sufficient as possible. This literature review demonstrates that some variations of names for ECs can be quite useful because they can instantly reveal information about the type and structure of the EC in question. However, this conclusion only applies to some of the terms used, such as ICES; others, such as green community, do not reveal any additional information about the EC. The use of those terms may decrease after the EU member states have implemented the directives concerning ECs into their local legal frameworks.

\subsection{Components of an energy community}

This section analyzes which components of an EC are actually used in the literature and how frequently. The components found are shown in Fig. 5 and can be clustered in: generation, storage and heating/cooling. Photovoltaics, wind powerplants, hydro powerplants, and biomass are all forms of generation, as is distributed generation (DG). It is not specified in those papers what type of energy generation is used. Wind power can be implemented in ECs in two ways: with micro-wind turbines at the household level or with full-scale wind turbines at the EC level. According to Meister et al.'s analysis for Germany, the median wind capacity in ECs is $4.8 \mathrm{MW}$, indicating that wind power is typically used at the community level [4]. ECs powered solely by wind turbines were rarely described in the literature. [25] is an example of when this is important, as the case study is located in Finland, an area with insufficient irradiance for PV. Combining PV and micro-wind generation could be a solution for ECs with consumers who have comparable consumption patterns (e.g. remote villages) [14]. Full-scale wind farms in ECs can be found if the company that builds them is a member of the EC, or if multiple small ECs merge to afford it [3,23]. Electric vehicles (EVs) can be viewed as both a source of energy (vehicle to grid) and storage. The application of EVs in ECs is versatile. It can be integrated very actively with bidirectional vehicle to grid (V2G) charging and thus functions as an intermittently unavailable battery [54]. In that case, the energy stored in the EVs can be used in a local market or aggregated and sold on the wholesale market $[48,49]$. They can also play a less active role as an interruptible load, in which case optimized charging schedules are critical to avoid interfering with consumer comfort [56]. EVs, regardless of their level of activeness,

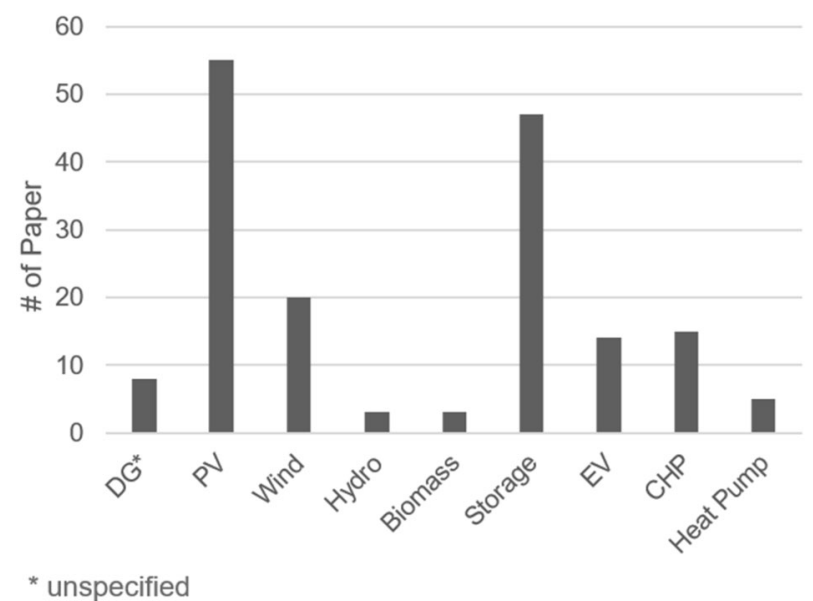

Fig. 5. Classification of papers by components of an energy community

can be used in demand side management (DSM) for load shifting. With increasing EV penetration, involving EV management in ECS is becoming more important to prevent grid straining load peaks. Bidirectional use can also reduce the need for expensive storage capacity [65]. Charging outside the home is not very common in the analyzed literature. Wang et al. [63] developed an EV charging scheme, but the system is centralized, thus it doesn't matter where in the MG the EV is parked, and it also doesn't matter if it is in a charging lot or at a house. Moura et al. [44] used parking lots in large commercial and public buildings for EVs to utilize their energy for flexibility purposes. In this approach, the EV owner receives lower parking rates if they agree to the flexibility use. Storage is another hybrid component because heat storage is classified as both heating and storage. Combined heat and power (CHP) is a hybrid between generation and heating/cooling. They are typically seen in ECs with a focus on sector coupling, such as ICESS and multi-energy communities. The manner in which the CHP is powered is critical. Supplying it with grid gas may have an impact on $\mathrm{CO}_{2}$ emissions and the EC's autarky level $[36,66]$. Another option is to power it with biogas derived from waste or agriculture. Yan et al. used an expanded version of this technology in [66]: combined cooling, heating, and power. It consists of a gas turbine generator, an absorption chiller, and a heat recovery boiler. Heat pumps (HP) are solely part of the heating/cooling cluster. The vast majority, i.e., $82 \%$, of papers include photovoltaics closely followed by storage with $70 \%$. PV is accessible as the price of solar panels dropped significantly over the last two decades [74]. Furthermore, they can be installed on rooftops and therefore do not necessarily take up extra space. Storage being in second place was not surprising. It is a way to increase the autarky and self-consumption levels of an EC without the need to significantly alter load patterns of the members. Two ways of implementation are presented in literature. Either the storage is part of one household and is also dimensioned as such or as a community energy storage. In terms of technology, batteries predominated, but heat storage was used in some papers. The two least used components in the analyzed papers are hydro power and biomass. The later can be mostly found in German ECs where farmers produce biomass from agricultural waste for electricity and/or heat production for the community as described in [72]. Table 1 provides a detailed breakdown of which components can be found in which analyzed paper. 


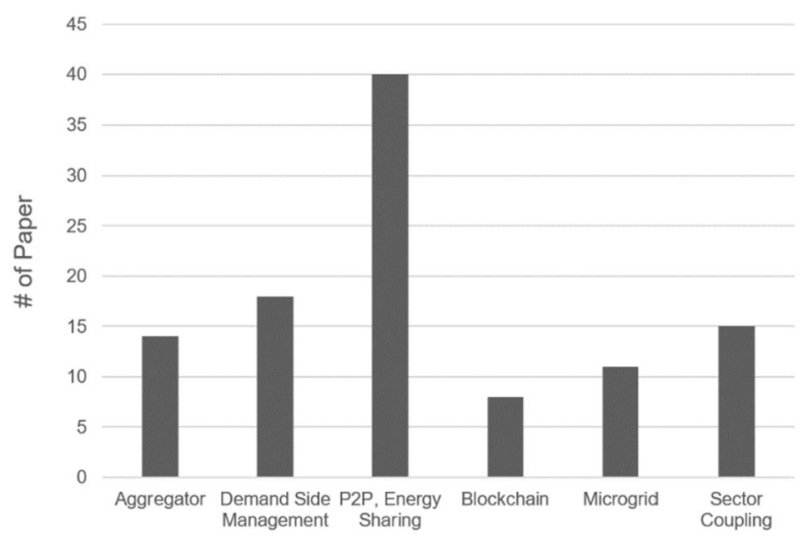

Fig. 6. Classification of papers by characteristics and structure of an energy community

\subsection{Characteristics and structure}

The characteristics and structure of the analyzed papers were classified into six sub-categories for this review, as shown in Fig. 6. The sub-categories are as follows: having an aggregator working within the $E C$, using some form of DSM, engaging in energy sharing or peer-to-peer trading, utilizing blockchain technology, being structured as a micro-grid, and implementing sector-coupling. An interesting outcome is that only around $16 \%$ of the papers are explicitly using a micro-grid. Considering the local scope limitation that is used in research this is a lot less than expected. Almost a quarter of the literature includes some sort of sector coupling with the heating sector. This starts with only including heat pumps to having a whole heat network throughout the community with CHP, solar heaters and gas boilers. Another characteristic that can be is referenced in literature about ECs is blockchain. This technology is used for creating smart contracts in a data-secure way in P2P trading. In the next paragraphs the three other analyzed characteristics aggregators, demand side management and P2P are described in more detail.

\subsubsection{Aggregator}

In around $20 \%$ of the papers the EC was working with an aggregator. They are seen as a neutral, third party entity connected by two-way communication to the community. This role can be taken on by e.g. the energy provider, retailer or the balance responsible party. The business model of an aggregator described in literature varies. They can work for- or non-profit and for a fee or on commission from the sales to the wholesale market $[16,18,26]$. The roles that are taken on by aggregators in those publications are quite varied. The first is as a manager/coordinator of various technological components in the energy community: micro-grid [63], consumption/load $[16,28,49,65]$, generation $[16,49,63,65]$, the surplus of it [44] and electrical vehicles [24, 44,63]. They also try to balance generation and load as well as to optimize some goal like minimal price or maximal self-consumption. This is often done with the help of demand side management, day-ahead operating scheduling and/or flexibility transaction $[28,49,65]$. The other side of an aggregator's work is the oversight of the energy trade inside and outside of the energy community. In the first case being the energy sharing coordinator for the internal market and in the second being in charge of buying/selling from/to the wholesale market. [24]

\subsubsection{Demand side management}

Under the term demand side management fall schemes that incentivize consumers to be more energy efficient. This can be short-term demand response (DR) but also longer-term or permanent energy efficiency techniques. DSM in an EC is of a lot of interest since a variety of consumers with different load profiles can be managed together. Members of ECS are expected to be more active, both with responsive loads and with their own energy production. While the obvious benefits of DSM are lower energy cost and reduction of load peaks, with increasing amounts of renewable energy sources (RES) in the system, improving grid reliability is another important perk. Especially for ECS when trying to reach their goals of minimized energy costs, maximized self-consumption or autarky. The results of [32] even suggest that DSM in ECs could replace expensive rarely used generators in the low-voltage grid in case of low and medium level power outages. They also claim that other problems in the distribution grid like voltage-constrained power transfer problems and congestion in substations could be solved with DSM. But it can also lead to issues like synchronization of demand. In [35] Good and Mancarella found out that if DR is not properly managed the incentive to shift load to an off-peak hour decreases normal load diversity which can even provoke capacity problems. Before implementing DSM there are still some elements that can be hindering as Koirala et al. point out in [6]. Smart meter roll outs are still not at a sufficient degree in most European countries [75]. Important information and communication infrastructures are not market-ready or still too expensive for the average consumer. And lastly DSM makes system operation even more complex. There are multiple methods and incentives for modifying energy consumption patterns. One is load shifting, where appliances are rescheduled to off-peak hours [15]. In [32] Fazeli et al. give examples for loads that are suitable for this: refrigerators, washing machines and dryers, dishwashers as well as warm water boilers. They also write about a more extreme method: load curtailment where loads are shut down or limited for a certain amount of time. Since it can lead to consumer discomfort the use of this method is kept to a minimum. In ECs that optimize towards or are in island mode this might be needed from time to time. DR programs utilize variable energy prices as an incentive for consumers to enforce the above-described methods. For this to be actually adopted by the consumers the divergence between peak and off-peak price has to be compelling [52]

\subsubsection{Peer-to-peer trading}

As depicted in Fig. 6 some sort of P2P trading or energy sharing is the most included characteristic of an EC in the analyzed literature. The scope of it can vary a lot as Jenkins et al. describe in [76]. In a fully P2P market, the distance between the trading parties is not relevant. They have a bilateral contract and settle on a price. P2P trade inside a micro-grid is depicted in a community-based market, which offers an energy sharing framework that incorporates pro- and consumers into an energy sharing zone. There, all trading entities are considered equal and agree on a single price. A greater degree of control is added in a hybrid P2P market method, in which the microgrid functions together as one trading entity. This concept is e.g. used in the paper from Cardoso et al. [21] where multiple energy communities trade their surplus energy with each other. The trading itself most of the time takes place on a trading platform. Those platforms vary in target group and services as Adu-Kankam et al. outline in [12]. While it can be aimed at producers, pro- and consumers for local energy trade they also can be directed to utility companies and retailers for platform-as-a-service or all of the above. Some of these articles encounter some limitations or unsolved questions. Jenkins et al. in [76] make the observation that the regulation of local energy markets still needs to be implemented. Before doing that the impact of them should be analyzed further. This is also a point that 
Cui et al. in [29] make because it is still not clear how exactly it impacts grid stability. Two other key aspects discussed in the literature are the issues of data privacy and (real-time) communication. To reduce those concerns and to ensure scalability Crespo-Vazquez et al. in [27] create a decentralized marked clearing process. Furthermore, the extensive bidirectional information flow required for P2P could be problematic for approaches that try to implement real-time communication, as Faia et al. describe in [31]. Especially, with upscaling the number of market participants.

\section{Conclusion}

This article provides an overview of the various topologies of energy communities described in the literature. The examination of EC terminology revealed that some terms are already well-defined, while others are simply different names for the same types of EC. When analyzing the most common components of ECs, results show that the majority of ECS in the literature generate their electricity with PV and include a storage system to reduce reliance on the grid. With respect to common characteristics and structure of ECs, we find that $\mathrm{P} 2 \mathrm{P}$ trading is an essential part of an EC. It enables the EC's energy flow to be optimized so that more locally produced energy can be consumed within the EC. Surprisingly a micro-grid only showed up in $16 \%$ of the analyzed literature which might indicate that they are not technologically necessary for the realization of ECs. Our findings also demonstrate that a third-party aggregator may be an important component in an energy community. As a result, we suggest that using aggregators is an excellent approach to make the development of energy communities easier, particularly for those who do not have a technical background. This literature review demonstrated the various approaches that research has developed for implementing an EC. Now, that REDII is implemented in national law, the next step is to put those concepts into action by widespread adoption of renewable energy communities.

Funding Note Open access funding provided by Graz University of Technology.

Publisher's Note Springer Nature remains neutral with regard to jurisdictional claims in published maps and institutional affiliations.

Open Access Dieser Artikel wird unter der Creative Commons Namensnennung 4.0 International Lizenz veröffentlicht, welche die Nutzung, Vervielfältigung, Bearbeitung, Verbreitung und Wiedergabe in jeglichem Medium und Format erlaubt, sofern Sie den/die ursprünglichen Autor(en) und die Quelle ordnungsgemäß nennen, einen Link zur Creative Commons Lizenz beifügen und angeben, ob Änderungen vorgenommen wurden. Die in diesem Artikel enthaltenen Bilder und sonstiges Drittmaterial unterliegen ebenfalls der genannten Creative Commons Lizenz, sofern sich aus der Abbildungslegende nichts anderes ergibt. Sofern das betreffende Material nicht unter der genannten Creative Commons Lizenz steht und die betreffende Handlung nicht nach gesetzlichen Vorschriften erlaubt ist, ist für die oben aufgeführten Weiterverwendungen des Materials die Einwilligung des jeweiligen Rechteinhabers einzuholen. Weitere Details zur Lizenz entnehmen Sie bitte der Lizenzinformation auf http://creativecommons.org/licenses/by/4.0/ deed.de.

\section{References}

1. Caramizaru, A., Uihlein, A., European Commission: Joint Research Centre. Energy communities: an overview of energy and social innovation.

2. Commission, E. (2019): Clean energy for all Europeans. Luxembourg. https://doi.org/ $10.2833 / 9937$

3. Vernay, A. L., Sebi, C. (2020): Energy communities and their ecosystems: a comparison of France and the Netherlands. Technol. Forecast. Soc. Change, 158. https://doi.org/ 10.1016/j.techfore.2020.120123.

4. Meister, T., Schmid, B., Seidl, I., Klagge, B. (2020): How municipalities support energy cooperatives: survey results from Germany and Switzerland. Energy, Sustain. Soc., 10(1), 18. https://doi.org/10.1186/s13705-020-00248-3.
5. Brummer, V. (2018): Community energy - benefits and barriers: a comparative literature review of Community Energy in the UK, Germany and the USA, the benefits it provides for society and the barriers it faces. Renew. Sustain. Energy Rev., 94, 187-196. https://doi.org/10.1016/j.rser.2018.06.013.

6. Koirala, B. P., Koliou, E., Friege, J., Hakvoort, R. A., Herder, P. M. (2016): Energetic communities for community energy: a review of key issues and trends shaping integrated community energy systems. Renew. Sustain. Energy Rev., 56, 722-744. https:// doi.org/10.1016/j.rser.2015.11.080

7. European Parliament (2018): Directive (EU) 2018/2001 of the European Parliament and of the Council on the promotion of the use of energy from renewable sources. Off. J. Eur. Union, 2018(L 328), 82-209. Online. https://eur-lex.europa.eu/legal-content/ EN/TXT/PDF/?uri=CELEX:32018L2001\&from=EN.

8. Parliament, E. (2019): Directive 2019/944 on common rules for the internal market for electricity. Off. J. Eur. Union, L 158/125, 18

9. McCabe, A., Pojani, D., Broese van Groenou, A. (2018): Social housing and renewable energy: community energy in a supporting role. Energy Res. Soc. Sci., 38, 110-113. https://doi.org/10.1016/j.erss.2018.02.005.

10. Soeiro, S., Ferreira Dias, M. (2020): Renewable energy community and the European energy market: main motivations. Heliyon, 6(7). https://doi.org/10.1016/j.heliyon. 2020.e04511.

11. Abada, I., Ehrenmann, A., Lambin, X. (2020): Unintended consequences: the snowball effect of energy communities. Energy Policy, 143, 111597. https://doi.org/10.1016/j. enpol.2020.111597.

12. Adu-Kankam, K. O., Camarinha-Matos, L. M. (2019): Emerging community energy ecosystems: analysis of organizational and governance structures of selected representative cases. IFIP Adv. Inf. Commun. Technol., 553, 24-40. https://doi.org/10.1007/ 978-3-030-17771-3_3.

13. Al Skaif, T., Schram, W., Litjens, G., Van Sark, W. (2017): Smart charging of community storage units using Markov chains. In 2017 IEEE PES innov. smart grid technol. Conf. Eur. ISGT-Europe 2017 - proc. (pp. 1-6). https://doi.org/10.1109//SGTEurope.2017. 8260177.

14. Alam, M., Ramchurn, S. D., Rogers, A. (2013): Cooperative energy exchange for the efficient use of energy and resources in remote communities. In Proceedings of the 12th international conference on autonomous agents and multiagent systems (p. 8). www.gshakti.org.

15. Albachrony, M. A., Ha, D. L., Tran, Q. T., Brun, A., Petit, M. (2019): Coordinated prosumer transaction based on load shifting and optimization. In Proc. 2019 IEEE PES innov. smart grid technol. Eur. ISGT-Europe 2019. https://doi.org/10.1109/ISGTEurope. 2019.8905709.

16. Belli, G., et al. (2017): An energy management model for energetic communities of smart homes: the power cloud. In Proc. 2017 IEEE 14th int. conf. networking, sens. control. ICNSC 2017 (pp. 158-162). https://doi.org/10.1109/ICNSC.2017.8000084.

17. Bere, J., Jones, C., Jones, S., Munday, M. (2017): Energy and development in the periphery: a regional perspective on small hydropower projects. Environ. Plan. C Polit. Space, 35(2), 355-375. https://doi.org/10.1177/0263774X16662029.

18. Bottaccioli, L., Patti, E., Acquaviva, A., Macii, E., Jarre, M., Noussan, M. (2021): A toolchain to foster a new business model for photovoltaic systems integration exploiting an Energy Community approach. In IEEE int. conf. emerg. technol. fact. autom. ETFA. https://doi.org/10.1109/ETFA.2015.7301559.

19. Cabrera, W., Benhaddou, D., Ordonez, C. (2016): Solar power prediction for smart community microgrid. In 2016 IEEE int. conf. smart comput. SMARTCOMP 2016. https://doi.org/10.1109/SMARTCOMP.2016.7501718.

20. Capaccioli, A., Poderi, G., Bettega, M., D'Andrea, V. (2016): Participatory infrastructuring of community energy. In ACM int. conf. proceeding ser. (Vol. 2, pp. 9-12). https:// doi.org/10.1145/2948076.2948089.

21. Cardoso, R. P., Hart, E., Pitt, J. V. (2019): Evolving robust policies for community energy system management. In GECCO 2019 - proc. 2019 genet. evol. comput. conf. (Vol. 1, pp. 1120-1128). https://doi.org/10.1145/3321707.3321763.

22. Cejka, S., Zeilinger, F., Veseli, A., Holzleitner, M. T., Stefan, M. (2020): A blockchainbased privacy-friendly renewable energy community. In SMARTGREENS 2020 - proc. 9th int. conf. smart cities green ICT syst. (pp. 95-103). https://doi.org/10.5220/ 0009391300950103

23. Chen, Y. W., Chang, J. M. (2015): EMaaS: cloud-based energy management service for distributed renewable energy integration. IEEE Trans. Smart Grid, 6(6), 2816-2824. https://doi.org/10.1109/TSG.2015.2446980.

24. Cheng, P. H., Huang, T. H., Chien, Y. W., Wu, C. L., Tai, C. S., Fu, L. C. (2020): Demandside management in residential community realizing sharing economy with bidirectional PEV while additionally considering commercial area. Int. J. Electr. Power Energy Syst., 116, 1615-1620. https://doi.org/10.1016/j.ijepes.2019.105512.

25. Chis, A., Koivunen, V. (2019): Coalitional game-based cost optimization of energ portfolio in smart grid communities. IEEE Trans. Smart Grid, 10(2), 1960-1970. https:/ doi.org/10.1109/TSG.2017.2784902.

26. Chis, A., Rajasekharan, J., Lundén, J., Koivunen, V. (2016): Demand response for renewable energy integration and load balancing in smart grid communities. In Eur. signal process. conf. (pp. 1423-1427). https://doi.org/10.1109/EUSIPCO.2016. 7760483. 
27. Crespo-Vazquez, J. L., Alskaif, T., Gonzalez-Rueda, A. M., Gibescu, M. (2021): A community-based energy market design using decentralized decision-making under uncertainty. IEEE Trans. Smart Grid, 12(2), 1782-1793. https://doi.org/10.1109/TSG. 2020.3036915.

28. Cruz, C., Palomar, E., Bravo, I., Gardel, A. (2019): Towards sustainable energy-efficient communities based on a scheduling algorithm. Sensors (Switzerland), 19(18). https:// doi.org/10.3390/s19183973.

29. Cui, S., Wang, Y. W., Shi, Y., Xiao, J. W. (2020): An efficient peer-to-peer energysharing framework for numerous community prosumers. IEEE Trans. Ind. Inform. 16(12), 7402-7412. https://doi.org/10.1109/TIl.2019.2960802.

30. De Villena, M. M., Boukas, I., Mathieu, S., Vermeulen, E., Ernst, D. (2020): A framework to integrate flexibility bids into energy communities to improve self-consumption. In IEEE power energy soc. gen. meet. https://doi.org/10.1109/PESGM41954.2020. 9282036.

31. Faia, R., Soares, J., Pinto, T., Lezama, F., Vale, Z., Corchado, J. M. (2021): Optimal model for local energy community scheduling considering peer to peer electricity transactions. IEEE Access, 9, 12420-12430. https://doi.org/10.1109/ACCESS.2021. 3051004.

32. Fazeli, A., Christopher, E., Johnson, C. M., Gillott, M., Sumner, M. (2011): Investigating the effects of dynamic demand side management within intelligent smart energy communities of future decentralized power system. In IEEE PES innov. smart grid technol. conf. eur. https://doi.org/10.1109/ISGTEurope.2011.6162619.

33. Fouad, M. M., Iskander, J., Shihata, L. A. (2020): Energy, carbon and cost analysis for an innovative zero energy community design. Sol. Energy, 206, 245-255. https://doi. org/10.1016/j.solener.2020.05.048.

34. Giordano, A., Mastroianni, C., Scarcello, L., Spezzano, G. (2020): An optimization model for efficient energy exchange in energy communities. In 2020 5th int. conf. fog mob. edge comput. FMEC 2020 (pp. 319-324). https://doi.org/10.1109/FMEC49853. 2020.9144901.

35. Good, N., Mancarella, P. (2019): Flexibility in multi-energy communities with electrical and thermal storage: a stochastic, robust approach for multi-service demand response. IEEE Trans. Smart Grid, 10(1), 503-513. https://doi.org/10.1109/TSG.2017.2745559.

36. Grosspietsch, D., Thömmes, P., Girod, B., Hoffmann, V. H. (2018): How, when, and where? Assessing renewable energy self-sufficiency at the neighborhood level. Environ. Sci. Technol., 52(4), 2339-2348. https://doi.org/10.1021/acs.est.7b02686.

37. Guo, Z., Li, G., Zhou, M., Feng, W. (2019): Resilient configuration approach of integrated community energy system considering integrated demand response unde uncertainty. IEEE Access, 7, 87513-87533. https://doi.org/10.1109/ACCESS.2019. 2924828.

38. Jenkins, M., Kockar, I. (2020): Impact of P2P trading on distributed generation curtailment in constrained distribution networks. Electr. Power Syst. Res., 189. https://doi. org/10.1016/j.epsr.2020.106666.

39. Kong, P. Y., Song, Y. (2020): Joint consideration of communication network and power grid topology for communications in community smart grid. IEEE Trans. Ind. Inform 16(5), 2895-2905. https://doi.org/10.1109/TII.2019.2912670.

40. Leithon, J., Werner, S., Koivunen, V., Talebi, S. P. (2019): Price-aware renewable energy management with transmission losses. In ICASSP, IEEE int. conf. acoust. speech signal process. - proc. (pp. 8087-8091). https://doi.org/10.1109/ICASSP.2019.8683219.

41. Mediwaththe, C. P., Blackhall, L. (2020): Community energy storage-based energy trading management for cost benefits and network support. In Proc. - 2020 int conf. smart grids energy syst. SGES 2020 (pp. 516-521). https://doi.org/10.1109/ SGES51519.2020.00097.

42. Mehinovic, A., Borovina, D., Zajc, M., Souvent, A., Suljanovic, N. (2020): Local energy exchange using energy community interaction matrix. In IEEE PES innov. smart grid technol. conf. Eur. (pp. 1065-1069). https://doi.org/10.1109/ISGT-Europe47291. 2020.9248802.

43. Meinke, R. J., Sun, H., Jiang, J. (2020): Optimising demand and bid matching in a peerto-peer energy trading model. In IEEE int. conf. commun. https://doi.org/10.1109/ ICC40277.2020.9148652.

44. Moura, P., Yu, G. K. W., Mohammadi, J. (2020): Management of electric vehicles as flexibility resource for optimized integration of renewable energy with large buildings. In IEEE PES innov. smart grid technol. conf. Eur. (pp. 474-478). https://doi.org/10. 1109/ISGT-Europe47291.2020.9248808.

45. Negeri, E., Baken, N. (2012): Smart integration of electric vehicles in an energy community. In SMARTGREENS 2012 - proc. 1st int. conf. smart grids green IT syst. (pp. 25-32). https://doi.org/10.5220/0003952400250032.

46. Nidhin Mahesh, A., Sai Shibu, N. B., Balamurugan, S. (2019): Conceptualizing blockchain based energy market for self sustainable community. In BlockSys 2019 proc. 2019 work. blockchain-enabled networked sens. syst. (pp. 1-7). https://doi.org/ 10.1145/3362744.3363345

47. Okpako, O., Adamu, P. I., Rajamani, H. S., Pillai, P. (2017): Optimization of community based virtual power plant with embedded storage and renewable generation. In Lect. notes inst. comput. sci. soc. telecommun. eng. LNICST (Vol. 186, pp. 95-107). https:// doi.org/10.1007/978-3-319-53850-1_11.

48. Okpako, O., Rajamani, H. S., Pillai, P., Anuebunwa, U., Shanti Swarup, K. (2018): A comparative assessment of embedded energy storage and electric vehicle inte- gration in a community virtual power plant. In Lect. notes inst. comput. sci. soc. telecommun. eng. LNICST (Vol. 231, pp. 127-141). https://doi.org/10.1007/978-3319-76571-6_13.

49. Olivella-Rosell, P., et al. (2018): Local flexibility market design for aggregators providing multiple flexibility services at distribution network level. Energies, 11(4), 1-19. https://doi.org/10.3390/en11040822.

50. Oprea, S. V., Bara, A., Andreescu, A. I. (2020): Two novel blockchain-based market settlement mechanisms embedded into smart contracts for securely trading renewable energy. IEEE Access, 8, 212548-212556. https://doi.org/10.1109/ACCESS.2020. 3040764

51. Petri, I., Barati, M., Rezgui, Y., Rana, O. F. (2020): Blockchain for energy sharing and trading in distributed prosumer communities. Comput. Ind., 123. https://doi.org/10. 1016/j.compind.2020.103282

52. Pholboon, S., Sumner, M., Kounnos, P. (2016): Community power flow control for peak demand reduction and energy cost savings. In IEEE PES innov. smart grid technol. conf. eur. https://doi.org/10.1109/ISGTEurope.2016.7856276.

53. Prasad, A., Dusparic, I. (2019): Multi-agent deep reinforcement learning for zero energy communities. In 2019 IEEE PES innovative smart grid technologies Europe (ISGTEurope) (pp. 1-5). https://doi.org/10.1109/ISGTEurope.2019.8905628,

54. Rastegar, M., Fotuhi-Firuzabad, M., Zareipour, H., Moeini-Aghtaieh, M. (2017): A probabilistic energy management scheme for renewable-based residential energy hubs. IEEE Trans. Smart Grid, 8(5), 2217-2227. https://doi.org/10.1109/TSG.2016. 2518920.

55. Rathnayaka, A. J. D., Potdar, V. M., Dillon, T., Hussain, O., Kuruppu, S. (2014): Goaloriented prosumer community groups for the smart grid. IEEE Technol. Soc. Mag., 33(1), 41-48. https://doi.org/10.1109/MTS.2014.2301859.

56. Reis, I. F. G., Goncalves, I., Lopes, M. A. R., Antunes, C. H. (2019): Residential demandside flexibility in energy communities: a combination of optimization and agent modeling approaches. In SEST 2019 - 2nd int. conf. smart energy syst. technol. https://doi. org/10.1109/SEST.2019.8849152.

57. Sato, S., Weidlich, A. (2020): Analysis of avoided transmission through decentralized photovoltaic and battery storage systems. IEEE Trans. Sustain. Energy, 11(3), 1922-1929. https://doi.org/10.1109/TSTE.2019.2946446.

58. Savelli, I., Cornelusse, B., Paoletti, S., Giannitrapani, A., Vicino, A. (2019): A local market model for community microgrids. In Proc. IEEE conf. decis. control (pp. 2982-2987). https://doi.org/10.1109/CDC40024.2019.9029414.

59. Saxena, S., Farag, H., Brookson, A., Turesson, H., Kim, H. (2019): Design and field implementation of blockchain based renewable energy trading in residential communities. In 2019 2nd international conference on smart grid and renewable energy (SGRE) (pp. 1-6). https://doi.org/10.1109/SGRE46976.2019.9020672.

60. Scheller, F., Johanning, S., Reichardt, S., Reichelt, D. G., Bruckner, T. (2018): Competition effects of simultaneous application of flexibility options within an energy community. In Int. conf. Eur. energy mark. EEM. https://doi.org/10.1109/EEM.2018.8470007.

61. Schiera, D. S., Minuto, F. D., Bottaccioli, L., Borchiellini, R., Lanzini, A. (2019): Analysis of rooftop photovoltaics diffusion in energy community buildings by a novel GIS- and agent-based modeling co-simulation platform. IEEE Access, 7, 93404-93432. https:// doi.org/10.1109/ACCESS.2019.2927446.

62. Seven, S., Yao, G., Soran, A., Onen, A., Muyeen, S. M. (2020): Peer-to-peer energy trading in virtual power plant based on blockchain smart contracts. IEEE Access, 8 , 175713-175726. https://doi.org/10.1109/ACCESS.2020.3026180.

63. Wang, Y., Su, Z., Xu, Q., Yang, T., Zhang, N. (2019): A novel charging scheme for electric vehicles with smart communities in vehicular networks. IEEE Trans. Veh. Technol., 68(9), 8487-8501. https://doi.org/10.1109/TVT.2019.2923851.

64. Wijethunge, A. H., Wijayakulasooriya, J. V., Ekanayake, J. B., Polpitiya, A. (2019): Coordinated operation of the constituent components of a community energy system to maximize benefits while considering the network constraints. J. Electr. Comput. Eng., 2019. https://doi.org/10.1155/2019/5874962.

65. Yahaya, A. S., Javaid, N., Javed, M. U., Shafiq, M., Khan, W. Z., Aalsalem, M. Y. (2020): Blockchain-based energy trading and load balancing using contract theory and reputation in a smart community. IEEE Access, 8, 222168-222186. https://doi.org/10.1109/ ACCESS.2020.3041931.

66. Yan, B., et al. (2013): Energy-efficient management of eco-communities. In 2013 IEEE international conference on automation science and engineering (CASE) (pp. 106-111). https://doi.org/10.1109/CoASE.2013.6654057.

67. Ye, G., Li, G., Wu, D., Chen, X., Zhou, Y. (2017): Towards cost minimization with renewable energy sharing in cooperative residential communities. IEEE Access, 5, 11688-11699. https://doi.org/10.1109/ACCESS.2017.2717923.

68. Young, J., Brans, M. (2017): Analysis of factors affecting a shift in a local energy system towards $100 \%$ renewable energy community. J. Clean. Prod., 169, 117-124. https:// doi.org/10.1016/j.jclepro.2017.08.023

69. Zhang, M., Eliassen, F., Taherkordi, A., Jacobsen, H. A., Chung, H. M., Zhang, Y. (2019): Energy trading with demand response in a community-based P2P energy market. In 2019 IEEE int. conf. commun. control. comput. technol. smart grids, SmartGridComm 2019 (pp. 7-12). https://doi.org/10.1109/SmartGridComm.2019.8909798. 
70. Zhong, W., Xie, K., Liu, Y., Yang, C., Xie, S., Zhang, Y. (2020): Online control and nearoptimal algorithm for distributed energy storage sharing in smart grid. IEEE Trans. Smart Grid, 11(3), 2552-2562. https://doi.org/10.1109/TSG.2019.2957426.

71. Zou, L., Munir, M. S., Kim, K., Hong, C. S. (2020): Day-ahead energy sharing schedule for the P2P prosumer community using LSTM and swarm intelligence. In Int. conf. inf. netw. (pp. 396-401). https://doi.org/10.1109/ICOIN48656.2020.9016520.

72. Young, J., Brans, M. (2017): Analysis of factors affecting a shift in a local energy system towards 100\% renewable energy community. J. Clean. Prod., 169, 117-124. https:// doi.org/10.1016/j.jclepro.2017.08.023.

\section{Authors}

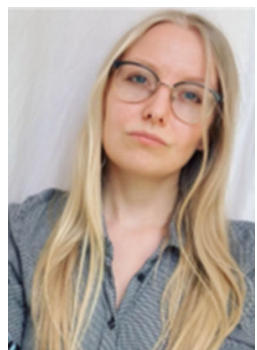

Lia Gruber

graduated from Graz University of Technology, Austria, in electrical engineering with honors in 2020. Currently she is working as a university assistant on her Ph.D. at the Institute of Electricity Economics and Energy Innovation also at Graz University of Technology. Her research interests are energy communities and renewable energy.

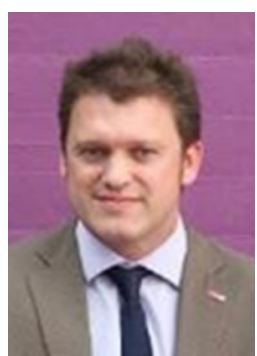

\section{Udo Bachhiesl}

studied Energy Economics at Graz University of Technology. During his scientific career Dr. Bachhiesl had research stays in Switzerland and France and gained working experience in the energy department of the federal state Styria/Austria. After completing his PhD and habilitation in the fields of energy innovation and energy economics Dr. Bachhiesl is at the moment deputy-head of the Institute of Elec-
73. Arnold, W., Lamparter, F. H. (1985): Friedrich Wilhelm Raiffeisen: einer für alle - alle für einen. Hänssler.

74. IEA (2020): Clean energy innovation: accelerating technology progress for a sustainable future.

75. Prettico, G., Flammini, M. G., Andreadou, N., Vitiello, S., Fulli, G., Masera, M. (2019): Distribution System Operators observatory 2018 Overview of the electricity distribution system in Europe. Luxenbourg. https://doi.org/10.2760/104777.

76. Jenkins, M., Kockar, I. (2020): Impact of P2P trading on distributed generation curtailment in constrained distribution networks. Electr. Power Syst. Res., 189, 106666. https://doi.org/10.1016/j.epsr.2020.106666.

tricity Economics and Energy Innovation at Graz University of Technology. Dr. Bachhiesl is an expert in the field of energy and electricity economics, renewable energies and energy innovation.

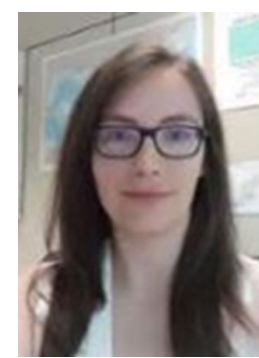

\section{Sonja Wogrin}

obtained a Dipl. Ing. (5-year degree) in Technical Mathematics from Graz University of Technology and a Master of Science in Computation for Design and Optimization at the Massachusetts Institute of Technology in 2008. She obtained her PhD in 2013 at the Institute for Research in Technology (IIT) from Comillas Pontifical University where she is Visiting Researcher. Currently, the is the Director of the Institute of Electricity Economics and Energy Innovation, and Full Professor at the Graz University of Technology. in the Industrial Organization Department. Her research interests lie within the area of decision support systems in the energy sector, optimization and modeling. 